\title{
Studying the Liver Function in Male Neonates of Rats Born to Sertraline- Treated Mothers
}

\author{
Safaei $\mathrm{V}^{1}$, Shariati $\mathrm{M}^{2}$ \\ ${ }^{\text {I}}$ Department of Biology, Shiraz Branch, Islamic Azad University, Shiraz, Iran \\ ${ }^{2}$ Department of Biology, Kazerun Branch, Islamic Azad University, Kazerun, Iran \\ Email: mehrdadshariati@kau.ac.ir
}

(received 06-11-2021; revised 24-11-2021; accepted 30-11-2021)

\begin{abstract}
ABSTRAK
Safaei V, Shariati M. Studi fungsi hati tikus neonates jantan untuk induk yang disertraline. JITV 26(4):132-138. DOI: http://dx.doi.org/10.14334/jitv.v26i4.2945.

Sertraline merupakan sebuah antidepresan yang memiliki efek racun pada hati. Penelitian ini dilaksanakan untuk mengevaluasi pengaruh penambahan Sertraline di masa kebuntingan pada fungsi hati tikus neonates jantan. Sebanyak 25 tikus Wistar betina bunting dibagi menjadi empat kelompok dengan jumlah masing masing sebanyak lima ekor. Kelompok control tidak mendapatkan perlakuan penambahan obat apapun, tetapi kelompok eksperimen (Exp) 1, 2 dan 3 menerima 5, 10 dan 20 $\mathrm{mg} / \mathrm{kg}$ berturut-turut Sertraline sebagai pakan paksa selama masa kebuntingan. Dua puluh dua hari setelah lahir, tikus jantan dibagi menjadi empat kelompok yang terdiri dari 10 ekor berdasarkan pembagian sebelumnya. Setelah ditimbang, sampel darah diambil langsung dari jantung. Kadar serum Alanine transaminase (Alt), Aspartate transaminase (AST), Alkaline phosphatase (Alp), Albumin (Alb), Total protein (TP), dan Bilirubin (Bili) diukur. Kemudian, jaringan hati juga dianalisis secara histopatologis setelah ditimbang. Pada kelompok Exp, terjadi penurunan berat badan, TP dan serum Alb yang signifikan dibandingkan dengan kelompok kontrol $(\mathrm{p}<0,05)$. Pada kelompok Exp 3, penurunan berat hati yang signifikan diamati dibandingkan dengan kelompok kontrol $(\mathrm{p}<0,05)$. Pada kelompok Exp 2 dan 3, terjadi peningkatan signifikan kadar serum Alp, Alt, dan Bili dibandingkan dengan kelompok kontrol $(\mathrm{p}<0,05)$. Sebuah peningkatan yang signifikan dalam tingkat serum AST diamati pada kelompok Exp dibandingkan dengan kelompok kontrol $(\mathrm{p}<0,05)$. Kerusakan jaringan hati diamati pada ketiga kelompok Exp. Pemberian Sertraline pada tikus betina bunting menyebabkan kerusakan hati dan meningkatkan enzim hati serta parameter biokimia darah pada keturunan jantannya.
\end{abstract}

Kata Kunci: Albumin, Perkembangan Hati, Enzim Hati, Tikus, Sertraline

\section{ABSTRACT}

Safaei V, Shariati M. Studying the liver function in male neonates of rats born to sertraline-treated mothers. JITV 26(4):132138. DOI: http://dx.doi.org/10.14334/jitv.v26i4.2945

Sertraline is an antidepressant which has toxic effects on the liver. This study was conducted to evaluate the effect of Sertraline administration in pregnancy on liver function of male neonates of rats. Twenty-five pregnant female Wistar rats were divided into 4 groups of 5 . The control group did not receive any drug treatments, but experimental (Exp) groups 1, 2 and 3 received 5, 10 and $20 \mathrm{mg} / \mathrm{kg}$ Sertraline as gavage throughout the pregnancy, respectively. Twenty-two days after birth, male rats were divided into 4 groups of 10 based on the previous division and after weighing, by taking blood directly from the heart, serum levels of Alanine transaminase (Alt), Aspartate transaminase (AST), Alkaline phosphatase (Alp), Albumin (Alb), Total protein (TP), and Bilirubin (Bili) were measured and the liver tissue was also analyzed histopathologically after weighing. In Exp groups, a significant decrease in body weight, TP and Alb serum levels were observed compared to the control group $(p<0.05)$. In Exp group 3, a significant decrease in liver weight was observed compared to the control group ( $<<0.05)$. In Exp groups 2 and 3, a significant increase in serum levels of Alp, Alt and Bili in was observed compared to the control group $(\mathrm{p}<0.05)$. A significant increase in AST serum level was observed in Exp groups compared to the control group ( $<<0.05)$. Liver tissue destruction was observed in all 3 Exp groups. The administration of Sertraline in pregnant female rats causes liver damage and increases liver enzymes and blood biochemical parameters in their male offspring.

Key Words: Albumin, Liver Development, Liver Enzymes, Rat, Sertraline

\section{INTRODUCTION}

Depression is a common and recurrent disorder that reduces the functional and cognitional role and even in some cases, it leads to death (Wang et al. 2017). Sertraline is a drug that is widely used in the treatment of depression. It is used in a wide range of psychiatric disorders, including panic disorder, obsessive- 
compulsive disorder, and post-traumatic stress disorder. Sertraline also acts as an appetite suppressant in weight loss. The most important drug activity of Sertraline is the inhibition of presynaptic Serotonin reuptake (Singh and Saadabadi, 2021). It also has very weak effects on norepinephrine and neuronal absorption of Dopamine (Suen et al. 2013) and it should not be used in combination with Monoamine oxidase (MAO) inhibitor (Aboukarr and Giudice, 2018). It is believed that Sertraline works by increasing the effects of Serotonin in the brain (Willard et al. 2015). By inhibiting Serotonin reuptake, extracellular Serotonin levels increase, thereby increasing serotonergic neurotransmitters in the brain. This action appears to be responsible for the antidepressant, anti-anxiety, and anti-obsessive effects of Sertraline. Sertraline has little tendency for Norepinephrine transporters or Serotonin, Dopamine, Adrenergic, Histamine, or Acetylcholine receptors. On the other hand, it shows a strong affinity for the Dopamine receptor and the $\sigma_{1}$ receptor (But not for the $\sigma_{2}$ ) (Albayrak and Hashimoto, 2017). Sertraline is slowly absorbed when taken orally and reaches a maximum plasma concentration 4 to 6 hours after ingestion and $98.5 \%$ of it binds to plasma proteins. Based on in vitro studies, Sertraline is metabolized by several cytochrome 450 isoforms (Chen et al. 2020). The active metabolite of Sertraline is Norsetraline (NDismethylsertraline) which is significantly less biologically active than Sertraline (McIntyre and Mallett, 2012).

The usual dose of Sertraline in the treatment of major depressive disorders is $50 \mathrm{mg}$ daily, which can be gradually increased to a maximum of $200 \mathrm{mg}$ per day which is guided by the therapeutic response (Honko et al. 2017). The side effects of Sertraline include nausea, diarrhea, insomnia, and sexual dysfunction. Acute secondary hepatitis after Sertraline use is rare, but given the widespread use of Sertraline, awareness of this side effect is important to ensure early diagnosis (Suen et al. 2013). Sertraline is one of the most commonly used antidepressant during pregnancy, and generally recognized safe for this use (Molenaar et al. 2020). Nevertheless, the findings represent that the administration of Sertraline during pregnancy is associated with an increase of this drug in fetal amniotic fluid. Therefore, it seems that the fetus is exposed to this drug through various routes such as placenta and digestion. Also, studies measuring the concentration of Sertraline and its major metabolite, dismethylsertraline, in maternal blood and umbilical cord blood show that the serum concentration of Sertraline in the umbilical cord is almost always lower than the maternal serum concentration (Hostetter et al. 2000, Horackova et al. 2021). The concentrations of Sertraline and dismethylsertraline in breast milk are highly variable and, on average, are equally concentrated as the maternal blood plasma (Pinheiro et al. 2015).

Some studies indicate that hepatotoxicity following Sertraline administration is negligible, but some other studies show that Sertraline is associated with toxicity and liver damage (Tabak et al. 2009; Todorović Vukotić et al. 2021). Because there are not enough findings about the effect of Sertraline on liver tissue and Sertraline is one of the most widely used antidepressants and the effect of this drug in pregnancy on fetal liver function is unknown, therefore, this study was conducted to evaluate the effect of Sertraline on the liver tissue of neonates of male rats born to mothers who have been exposed to different doses of Sertraline during pregnancy. For this purpose, body weight, liver weight, serum levels of liver enzymes and some blood biochemical parameters as well as histopathological changes of the liver were evaluated in this study.

\section{MATERIALS AND METHODS}

\section{Animals}

In this experimental study, 20 adult female Wistar rats weighing $190 \pm 10 \mathrm{~g}$ were provided from the animal's house at Islamic Azad University of Kazerun and were kept in the standard conditions at $23 \pm 2{ }^{\circ} \mathrm{C}, 12$ hours of light/darkness, and $70 \%$ moisture in 5individual groups in polycarbonate cages with dimensions of $15 \times 2.5 \times 40 \mathrm{~cm}$ with steel mesh roof. In order to adapt to the new environmental conditions, the animals were kept together for 2 weeks. The animals received the same amount of water and food throughout the study without any restrictions. The ethical principles of working with laboratory animals were observed in this study and approved by the Ethics Committee of Islamic Azad University of Kazerun (Ethical code no: IR.IAU.SHIRAZ.51053279901007).

\section{The Experiment Protocol}

The pregnant female rats $(n=20)$ were divided into 4 groups of 5 including control, experimental 1 (Exp 1), experimental $2(\operatorname{Exp} 2)$ and experimental $3(\operatorname{Exp} 3)$. The control group did not receive any drug treatment. Animals in Exp groups 1, 2 and 3 received 5, 10 and 20 $\mathrm{mg} / \mathrm{kg}$ Sertraline (Zoloft, Pfizer, Germany), respectively, at 9 a.m. every day until the end of pregnancy as a gavage. The doses prescribed in this study were determined based on the previous studies (Mikail et al. 2012; Pereira-Figueiredo et al. 2014). The duration of breastfeeding in male rats from sertralinetreated mothers was 3 weeks. Twenty two days after delivery, male neonates of female rats were divided into 4 groups of 4 as in the previous division. At the end of day 22, male rats were anesthetized with ether (Merck, 
Germany), and blood samples were taken directly from the heart, and then liver tissue was removed for histopathological evaluation.

\section{Analysis of Blood Parameters}

For blood sampling, the animals were first weighed and then anesthetized using ether and opening the chest; blood was drawn directly from the heart with a $5 \mathrm{ml}$ syringe. In order to perform the agglutination process, blood samples were kept in the laboratory for 30 minutes and then centrifuged at $3000 \mathrm{rpm}$ for 5 minutes. The resulting sera were frozen at $-20^{\circ} \mathrm{C}$ until serum levels of Alanine transaminase (Alt), Aspartate transaminase (AST), Alkaline phosphatase (Alp), Albumin (Alb), Total protein (TP) and Bilirubin (Bili) were measured.

Serum levels of AST, ALT, ALP, Alb and TP were measured by RA-1000 auto-analyzer (Technicon, USA) according to the manufacturer's instructions (Pars Azmoon Company, Iran). Serum ALT and AST levels were measured by IFCC (international federation of clinical chemistry) method without the addition of Pyridoxal-50phosphate and serum ALP level was measured by PGKC (Deutsche Gesellschaft Fur Klinische Chemie) method. Also, serum Tp level was measured by photometric method based on Biuret method and serum Alb level was measured by BROMOCRESOL-GREE method. (Letafat et al. 2021)

\section{Liver Tissue Changes Analysis}

For histopathological examination of the liver, the abdominal cavity of all animals was opened and the liver was removed. First, the liver weight of all animals was calculated and then the tissue samples were washed with normal saline and fixed in $10 \%$ formalin buffer solution. The dehydration process of the samples was performed in $60 \%$ to absolute alcohol and the tissue samples were clarified with Xylene. Tissue samples were molded with paraffin and then 10 transverse sections with a thickness of 5 microns were prepared from each sample using a rotating microtome. Under a light microscope (Nikon, Japan), 5 different areas of each cross section were randomly selected and tissue changes were examined. The amount of empty space created due to hepatocyte necrosis was examined in different samples with 40x magnification.

\section{Statistical Analysis}

Using Kolmogorov-Smirnov test (SPSS Statistics version 20, SPSS Inc., Chicago, IL), the normal distribution of data was first investigated and then, using one way ANOVA test and Tukey post hoc test, statistical comparison was performed between control and Exp groups at the level of $p<0.05$. Results were presented as mean \pm mean standard deviation in the graph (GraphPad Prism 6, Inc., San Diego, CA, USA) and table.

\section{RESULTS AND DISCUSSION}

In Exp groups 1, 2 and 3 (Figure 1A) a significant decrease in body weight (Figure 1A) was observed compared to the control group $(p<0.05)$. There was no difference in liver weight (Figure 1B) in Exp groups 1 and 2 compared to the control group ( $p>0.05)$, but in Exp group 3, a significant decrease was observed compared to the control group $(\mathrm{p}<0.05)$. There was no difference in serum levels of Alt, Alp and Bil (Figure $1 \mathrm{C}, 1 \mathrm{D}$ and 1E, respectively) in Exp groups 1 compared to the control group ( $>00.05)$, but in Exp groups 2 and 3 , a significant increase was observed compared to the control group $(\mathrm{p}<0.05)$. A significant increase in serum AST levels (Figure 1F) was observed in Exp groups 1, 2 and 3 compared to the control group $(\mathrm{p}<0.05)$. Also, a significant decrease in serum levels of $\mathrm{TP}$ and $\mathrm{Alb}$ (Figure $1 \mathrm{G}$ and $1 \mathrm{H}$, respectively) was observed in Exp groups 1, 2 and 3 compared to the control group $(p<0.05)$. In the present study, the administration of Sertraline in doses of 5,10 and $20 \mathrm{mg} / \mathrm{kg}$ of body weight caused liver necrosis, weight loss and liver weight loss in Exp groups. Also, serum levels of Alt, AST, Alp and Bili also increased, while serum levels of Alb and TP decreased. Sertraline is one of the most common Serotonin reuptake inhibitors, which is considered as a safe drug during pregnancy (Molenaar et al. 2020). Plasma concentrations of Sertraline may decrease or increase during pregnancy, but no clear association has been found between different doses of Sertraline and its associated clinical effects. Although the rate of Sertraline passage through the placenta is very low, its side effects on fetal tissues and organs are unclear. Sertraline is generally a weak compound that binds to two plasma proteins, Albumin, and more to alpha 1-acid-glycoprotein. Plasma levels of Albumin and alpha-1-acid-glycoprotein decrease during pregnancy so they can affect the plasma concentration of Sertraline (Heinonen et al. 2021). At birth, however, plasma Albumin concentrations in infants are usually higher than in mothers, while the plasma concentration of alpha 1-acid-glycoprotein is one third of the maternal plasma concentration (Ewing et al. 2015).

The enzyme family of cytochrome P450 plays an important role in the metabolism of Sertraline to its major and weak metabolite, dismethylsertraline (Huddart et al. 2020). It seems that any change in the expression of cytochrome P450 family enzymes can affect the plasma concentration of Sertraline. One of these factors is pregnancy, which can induce changes in the activity of metabolic enzymes (Westin et al. 2017). 


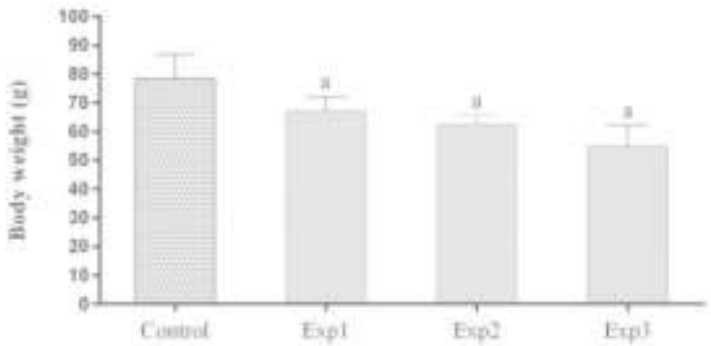

A

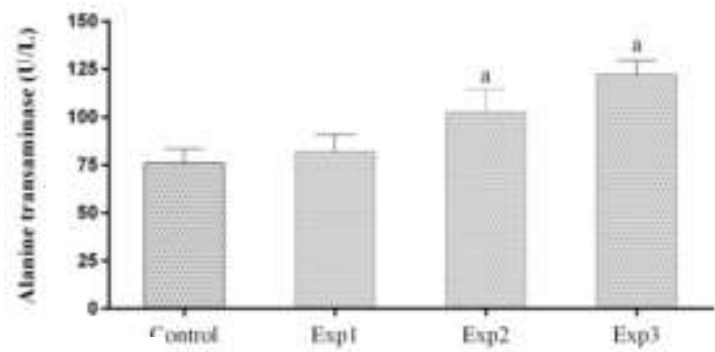

C

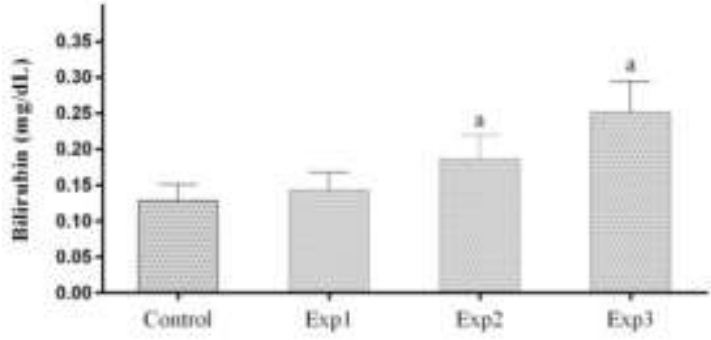

$\mathbf{E}$

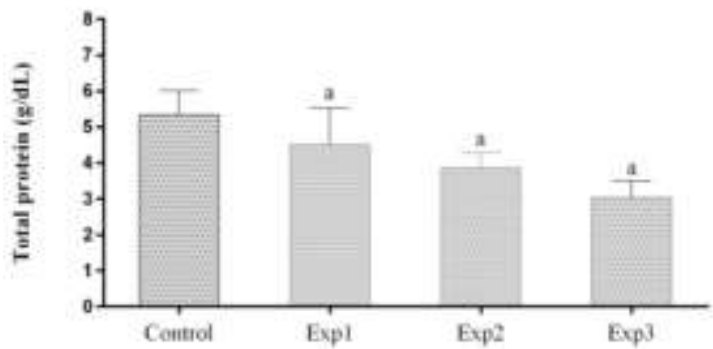

G

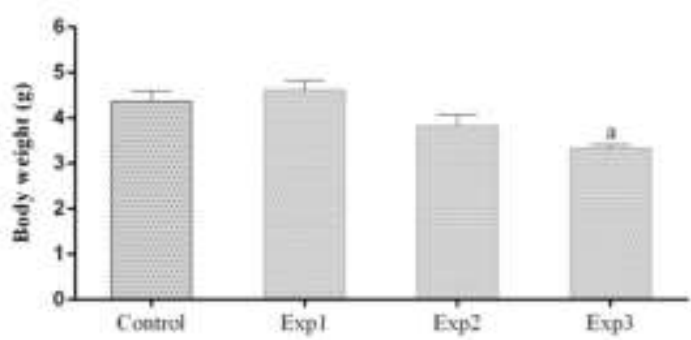

B

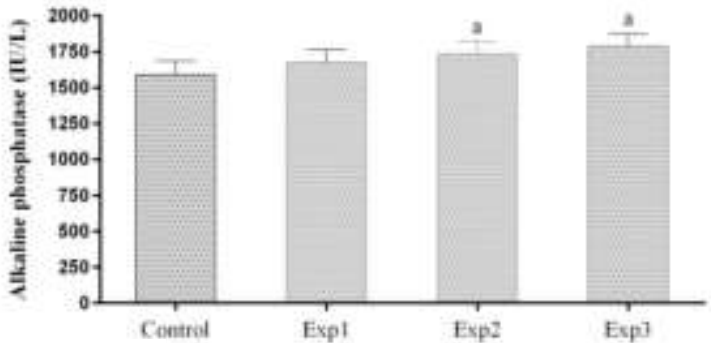

D

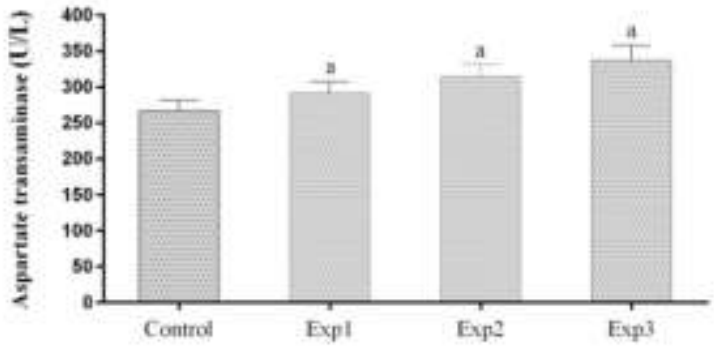

F

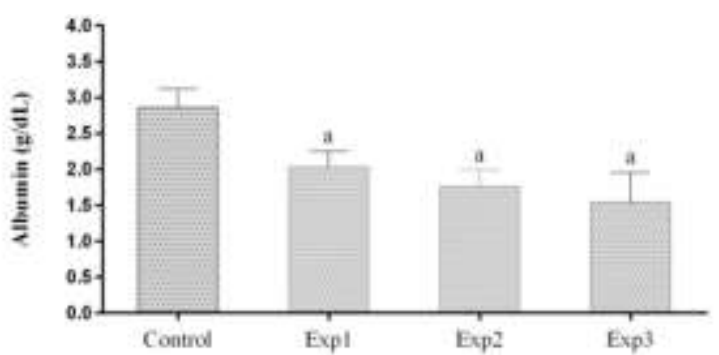

$\mathbf{H}$

Figure 1. Comparison of mean and standard deviation of mean A) body weight, B) liver weight, C) Alt, D) Alp, E) Bili, F) AST, G) TP and H) Alb levels in control, Exp groups 1, 2 and 3. a $(\mathrm{p}<0.05)$ : compared with the control group.

Serotonin is a neurotransmitter that plays an important role in controlling the appetite and it is directly related to the amount of Tryptophan in the diet and its amount in the brain changes as the amount of Tryptophan decreases or increases. Serotonin receptors inhibit the function of neuropeptide $\mathrm{Y}$, a potent stimulant of hunger and food absorption. Decreased activity of this neuropeptide may be associated with increased activity of Leptin. Leptin is made by adipose tissue in the human body and travels to the brain through the bloodstream, acting on hypothalamic receptors and reduces the appetite (Yabut et al. 2019). Given the abovementioned, it is possible that Sertraline drug increases Leptin by increasing brain Serotonin and 
decreasing the function of neuropeptide $\mathrm{Y}$, resulting in decreased appetite and weight loss.

Serotonin reuptake inhibitors are commonly known to reduce serum levels of inflammatory cytokines such as TNF- $\alpha$ and IL-1 $\beta$ in patients with major depressive disorder (Hannestad et al. 2011). However, the effects of these Serotonin reuptake inhibitors, such as Sertraline, appear to be possible at low doses. The studies show that the administration of high doses of Sertraline in rats is associated with increased TNF- $\alpha$ and IL-1 $\beta$ mRNA expression (Sitges et al. 2014). In the present study, with increasing the dose of Sertraline, further destruction of liver tissue was observed. Therefore, due to the dose-dependent effects of the drug, the destruction of the liver parenchyma and the reduction of liver cell density could be a reason for weight loss.

Histopathological examination showed that (Figure 2 ) in the control group, the liver tissue is healthy and hepatocyte cells are regular and dense (Figure 2A). However, liver tissue degradation was observed in all 3
Exp groups. In Exp group 1, the liver parenchyma was slightly necrotic and some empty spaces were observed between hepatocyte cells (Figure 2B). In Exp groups 2 (Figure 2C) and 3 (Figure 2D), the liver parenchyma had moderate to severe necrosis, respectively, and empty spaces were observed between hepatocytes. In an in vivo study, significant morphometric and hepatic histological changes, such as hepatocyte necrosis and hydropic degeneration, were detected in Sertralinetreated rabbits orally $(8 \mathrm{mg} / \mathrm{kg})$ for 9 weeks, which was consistent with the histopathological results of this study. It was suggested that, the hepatic necrosis could indicate oxidative stress by glutathione depletion as a consequence of Sertraline toxicity (Almansour et al. 2018). The studies represent that Sertraline consumption during pregnancy is associated with shortterm and long-term adverse effects in children (Shen et al. 2017). Other studies also indicate that Sertraline can induce oxidative DNA damage and increase the level of cellular apoptosis (Jajoo et al. 2020). The studies suggest that Sertraline has teratogenic and toxic effects
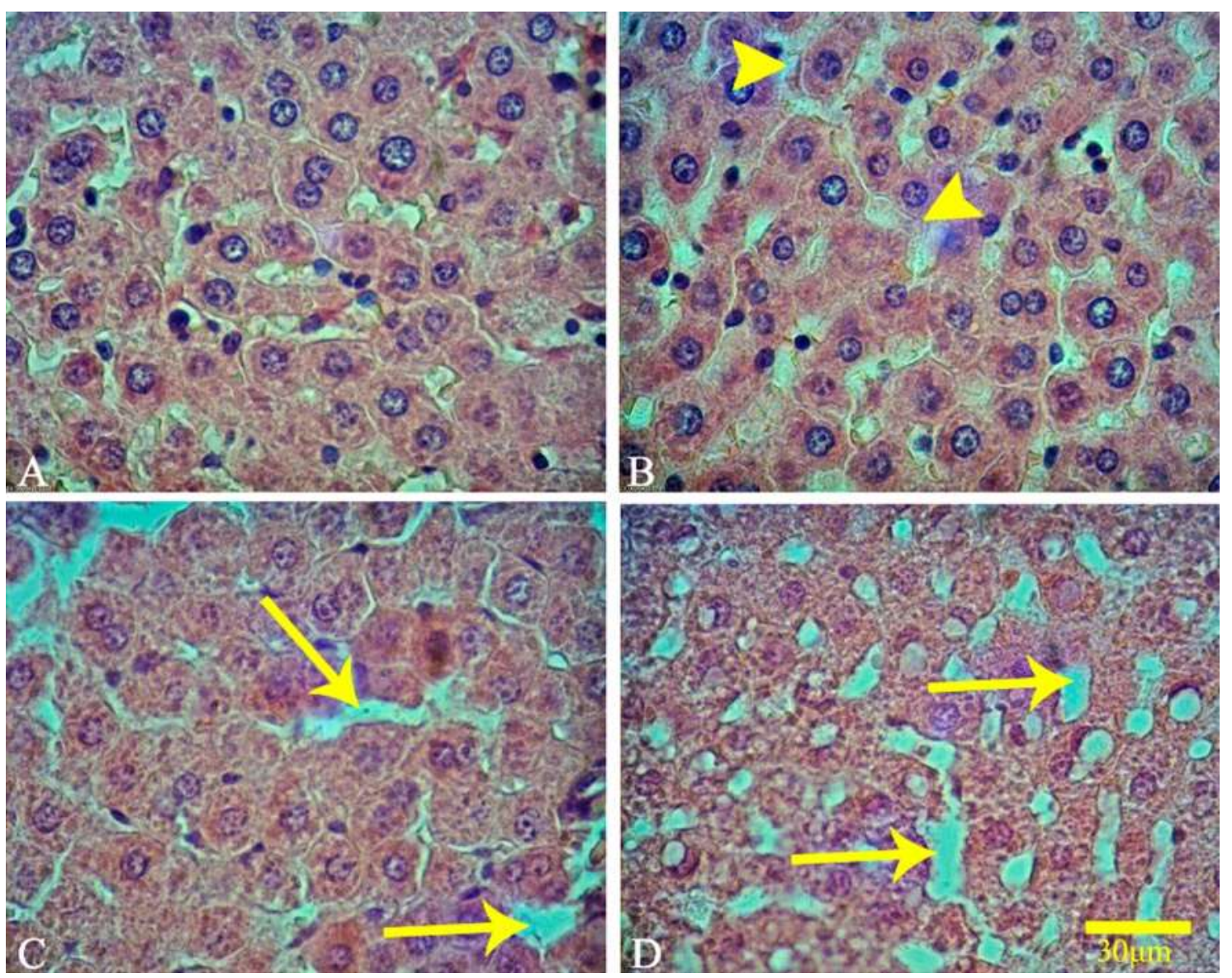

Figure 2. Optical photomicrograph of liver tissue of male rats born to mothers treated with Sertraline. A) In the control group, liver tissue has a normal structure, and healthy hepatocytes are observed. B) In the Exp1 group, very mild necrosis of liver tissue is observed. Damage and structural changes in liver tissue are minor (yellow arrows). C) In the Exp2 group, liver tissue necrosis is observed. Damage and structural changes in liver tissue are moderate (yellow arrows). D) In the Exp3 group, liver tissue necrosis is very severe and large vacuole spaces are observed between hepatocyte cells (yellow arrows). (E\&H staining, 40X) 
on the fetus. It seems that Sertraline can increase Serotonin (5-HT) receptors by altering Serotonin reuptake. 5-HT, as a messenger molecule, regulates many developmental events such as replication, migration, differentiation, and gene expression. Therefore, Sertraline seems to cause damage to various fetal tissues such as the liver by increasing Serotonin levels and increasing 5-HT (Wise et al. 2020). It has been suggested that some antidepressants, such as Sertraline and Fluoxetine, may inhibit P450 family enzymes, thereby increasing toxic metabolites in the liver. Therefore, it seems that the cause of liver necrosis is the increased serum levels of Alt, AST, Alp and Bili, as well as decreased Alb and TP in this study and the teratogenic and toxic effects of Sertraline on liver's development and function in male rats that is consistent with previous studies (Friedrich et al. 2016).

\section{CONCLUSION}

Dose-dependent administration of Sertraline in pregnant rats causes hepatic necrosis, increases serum levels of Alt, AST, Alp, and Bili, and decreases Alb and TP in their male neonates during 28 days. Sertraline at the maximum dose $(20 \mathrm{mg} / \mathrm{kg}$ of body weight) has the most destructive effects on liver tissue. Therefore, it is recommended to use this drug with more caution during pregnancy.

\section{ACKNOWLEDGMENT}

The authors would like to thank the vice chancellor for research, the Islamic Azad University of Shiraz, for their cooperation.

\section{REFERENCES}

Aboukarr A, Giudice M. 2018. Interaction between monoamine oxidase B inhibitors and selective serotonin reuptake inhibitors. Can J Hosp Pharm. 71:196-207.

Albayrak Y, Hashimoto K. Sigma-1 receptor agonists and their clinical implications in neuropsychiatric disorders. Adv Exp Med Biol. 2017;964:153-161. DOI: 10.1007/978-3-319-50174-1_11.

Almansour MI, Jarrar YB, Jarrar BM. 2018. In vivo investigation on the chronic hepatotoxicity induced by Sertraline. Environ Toxicol Pharmacol. 61:107-115. DOI: 10.1016/j.etap.2018.05.021.

Chen S, Wu Q, Li X, Li D, Fan M, Ren Z, et al. 2020. The role of hepatic cytochrome P450s in the cytotoxicity of Sertraline. Arch Toxicol. 94:2401-2411. DOI: 10.1007/s00204-020-02753-y.

Ewing G, Tatarchuk Y, Appleby D, Schwartz N, Kim D. 2015. Placental transfer of antidepressant medications: implications for postnatal adaptation syndrome. Clin
Pharmacokinet. 54:359-370. DOI: 10.1007/s40262014-0233-3.

Friedrich ME, Akimova E, Huf W, Konstantinidis A, Papageorgiou K, Winkler D, Toto S, Greil W, Grohmann R, Kesper S. 2016. Drug-induced liver injury during antidepressant treatment: results of AMSP, a drug surveillance program. Int J Neuropsychopharmacol. 19:pyv126. DOI: 10.1093/ijnp/pyv126.

Hannestad J, DellaGioia N, Bloch M. 2011. The effect of antidepressant medication treatment on serum levels of inflammatory cytokines: a meta-analysis. Neuropsychopharmacology. 36: 2452-2459.

Heinonen E, Blennow M, Blomdahl-Wetterholm M, Hovstadius M, Nasiell J, Pohanka A, et al. 2021. Sertraline concentrations in pregnant women are steady and the drug transfer to their infants is low. Eur J Clin Pharmacol. 77:1323-1331. DOI: 10.1007/s00228-02103122-z.

Honko AN, Johnson JC, Marchand JS, Huzella L, Adams RD, Oberlander N, et al. 2017. High dose Sertraline monotherapy fails to protect rhesus macaques from lethal challenge with Ebola virus Makona. Sci Rep. 7:5886. DOI: $10.1038 / \mathrm{s} 41598-017-06179-\mathrm{y}$.

Horackova H, Karahoda R, Cerveny L, Vachalova V, Ebner R, Abad C, Staud F. 2021. Effect of selected antidepressants on placental homeostasis of Serotonin: Maternal and Fetal Perspectives. Pharmaceutics. 13:1306. DOI: 10.3390/pharmaceutics13081306.

Hostetter A, Ritchie JC, Stowe ZN. 2000. Amniotic fluid and umbilical cord blood concentrations of antidepressants in three women. Biol Psychiatry. 48:1032-4.

Huddart R, Hicks JK, Ramsey LB, Strawn JR, Smith DM, Bobonis Babilonia M, et al. 2020. PharmGKB summary: sertraline pathway, pharmacokinetics. Pharmacogenet Genomics. 30:26-33. DOI: 10.1097/FPC.0000000000000392.

Jajoo A, Donlon C, Shnayder S, Levin M, McVey M. 2020. Sertraline induces DNA damage and cellular toxicity in Drosophila that can be ameliorated by antioxidants. Sci Rep. 10:4512. DOI: 10.1038/s41598-020-61362-y.

Letafat Farashbandi A, Shariati M, Mokhtari M. 2021. Comparing the protective effects of curcumin and ursodeoxycholic acid after ethanol-induced hepatotoxicity in rat liver. Ethiop J Health Sci. 31 :673.

McIntyre IM, Mallett P. 2012. Sertraline concentrations and postmortem redistribution. Forensic Sci Int. 223:349-52. DOI: 10.1016/j.forsciint.2012.10.020.

Mikail HG, Dalla C, Kokras N, Kafetzopoulos V, Papadopoulou-Daifoti Z. 2012. Sertraline behavioral response associates closer and dose-dependently with cortical rather than hippocampal serotonergic activity in the rat forced swim stress. Physiol Behav. 107:201-206.

Molenaar NM, Bais B, Lambregtse-Van Den Berg MP, Mulder CL, Howell EA, Fox NS, et al. 2020. The international prevalence of antidepressant use before, during, and after pregnancy: a systematic review and 
meta-analysis of timing, type of prescriptions and geographical variability. J Affect Disord. 264:82-89. DOI: 10.1016/j.jad.2019.12.014.

Pereira-Figueiredo I, Sancho C, Carro J, Castellano O, López DE. 2014. The effects of Sertraline administration from adolescence to adulthood on physiological and emotional development in prenatally stressed rats of both sexes. Front Behav Neurosci. 8:260.

Pinheiro E, Bogen DL, Hoxha D, Ciolino JD, Wisner KL. 2015. Sertraline and breastfeeding: review and metaanalysis. Arch Womens Ment Health. 18:139-146. DOI: 10.1007/s00737-015-0499-y.

Shen ZQ, Gao SY, Li SX, Zhang TN, Liu CX, Lv HC, et al. 2017. Sertraline use in the first trimester and risk of congenital anomalies: a systemic review and metaanalysis of cohort studies. Br J Clin Pharmacol. 83:909922. DOI: $10.1111 / \mathrm{bcp} .13161$.

Singh HK, Saadabadi A. Sertraline. 2021. In: StatPearls [Internet]. Treasure Island (FL): StatPearls Publishing.

Sitges M, Gómez CD, Aldana BI. 2014. Sertraline reduces IL$1 \beta$ and TNF- $\alpha$ mRNA expression and overcomes their rise induced by seizures in the rat hippocampus. PLoS One. 9:e111665. DOI: 10.1371/journal.pone.0111665.

Suen CF, Boyapati R, Simpson I, Dev A. 2013. Acute liver injury secondary to Sertraline. BMJ Case Rep. 26:bcr2013201022. DOI: 10.1136/bcr-2013-201022.

Tabak F, Gunduz F, Tahan V, Tabak O, Ozaras R. 2009. Sertraline hepatotoxicity: report of a case and review of the literature. Dig dis sci. 54:1589-1591.
Todorović Vukotić N, Đorđević J, Pejić S, Đorđević N, Pajović SB. 2021. Antidepressants- and antipsychoticsinduced hepatotoxicity. Arch Toxicol. 95:767-789. DOI: 10.1007/s00204-020-02963-4.

Wang J, Wu X, Lai W, Long E, Zhang X, Li W, et al. 2017. Prevalence of depression and depressive symptoms among outpatients: a systematic review and metaanalysis. BMJ Open. 7:e017173. DOI: 10.1136/bmjopen-2017-017173.

Westin AA, Brekke M, Molden E, Skogvoll E, Spigset O. 2017. Selective serotonin reuptake inhibitors and venlafaxine in pregnancy: changes in drug disposition. PLoS One. 12:e0181082. DOI: 10.1371/journal.pone.0181082.

Willard SL, Uberseder B, Clark A, Daunais JB, Johnston WD, Neely D,et al. 2015. Long term Sertraline effects on neural structures in depressed and nondepressed adult female nonhuman primates. Neuropharmacology. 99:369-78. DOI:10.1016/j.neuropharm.2015.06.011.

Wise LD, Dostal LA, DeSesso JM. 2020. The teratogenic effects of Sertraline in mice. Birth Defects Res. 112:1025-1027. DOI: 10.1002/bdr2.1751.

Yabut JM, Crane JD, Green AE, Keating DJ, Khan WI, Steinberg GR. 2019. Emerging roles for Serotonin in regulating metabolism: new implications for an ancient molecule. Endocr Rev. 40:1092-1107. DOI: 10.1210/er.2018-00283. 